\title{
Lusitan Identity Paradoxes Revealed by Fado Songs
}

\author{
Katarzyna Tomalak \\ Adam Mickiewicz University, Poznań, Poland
}

\begin{abstract}
This paper briefly presents the methods and the results of the investigation conducted within the doctoral study. The goal is to investigate the phenomenon of fado songs in the context of cultural transformations that take place in the uniting Europe. During the investigation, we tried to verify the problem of national and cultural identity of the Portuguese and their attitude towards ethno-cultural auto-identification in fado. According to the research results, the Portuguese are profoundly conscious of the relation between fado and their national and cultural identity. The results show that the Portuguese also consider the songs so strongly tied to their own nation, history, and places in Portugal, that this makes impossible for the foreigners to understand the message (even though some listeners claim, that they "feel" fado, though not being able to understand the lyrics). The research results proved that the Portuguese consider fado as a carrier of their identity, or even "Portuguese soul".
\end{abstract}

Keywords: cultural and national identity, fado, Portugal

\section{Introduction}

In today's globalized world, the question of preserving individual identity becomes a bipolar problem: On one hand, there is a strong tendency of unification, whereas ideologies and actions focused on preserving uniqueness of certain country, nation, or culture arise. Any action undertaken to save identity, difference, and unique character of certain community is worth surrounding it with special protection not to let it disappear in the global village reality. Not surprisingly, a boom in the musical market connected with fado has been observed for the last decade. More importantly, the significance of fado as a national song was recognized after Portugal had joined European Union. Reaction of the Portuguese seemed to be obvious and justified - related to a strong need of preserving their uniqueness and individual national character in the moment of entering into European structures. Nevertheless, observing the Portuguese, analyzing their behavior and attitudes, may lead to quite different conclusion.

Tourists visiting Portugal are charmed by songs they hardly understand, following general opinion which says that fado "expresses Portuguese soul". But is that in fact? Is fado the song of all the Portuguese? Does every Portuguese identify with the essence and character of fado? Or maybe it is only a kind of "Portuguese product" in European Union? All the abovementioned questions became a starting point for the investigation: Is fado a Portuguese identity carrier indeed? If that thesis was to be proved, we should show then in what ways the identity reveals: In which parts of the Portuguese society and what makes this phenomenon happen. As the main investigation problem lies on the border of a few scientific fields, it was necessary to identify an appropriate investigation methodology which would help in researching not only the problem of national and 
cultural identity of the Portuguese hidden in fado but also Portuguese attitude towards the question of ethno-cultural auto-identification in fado.

There are very few investigations conducted in this particular field, especially out of Portugal, which is on one hand a scientific challenge, but on the other hand is a threat of the problem being not sufficiently researched. The fluent command of Portuguese and the possibility to learn about the Portuguese society during numerous stays in Portugal let us observe phenomena, which became the beginning of our scientific queries and helped us crystallize the investigation problem of the doctoral dissertation ${ }^{1}$. Moreover, the geographical and national distance between the researcher from a different country in the European Union and the Portuguese society, created a very promising research perspective of an "intra-European distance".

Nevertheless, the investigation problem were not the fado songs themselves but the relation between them, their authors and their audience: The manner in which fado defines the Portuguese identity and the image of the Portuguese which is painted thanks to fado; the level of perception of the created image from the perspective of the Portuguese, but more importantly, the picture of the Portuguese painted by the foreigners through the fado.

As the scientific field, which best suits the concern of the research, was Ethnolinguistics it was decided to use qualitative methodology. Such complex research problem required appropriate investigation methods, therefore, it was decided to conduct the research through three qualitative methods: (1) a discourse analysis; (2) a questionnaire; and (3) unstructured interviewing. The first method was supposed to reveal the character and the scope of the nation and identity ideas in fado without an opinion interference or respondent's subjective attitude - throughout detailed and multidimensional discourse analysis. The second method was supposed to generate the answers to the questions related to specific, Lusitan perception of national and cultural matters reflexed by the unique for that culture and that nation songs. The aim of the third method was to deepen the problem focusing on the aspects previously investigated and revealed through the questionnaire as significant by grasping additional information thanks to the direct contact with the respondent.

Combining the results of the three research methods led us to conclusions with a broad scope. This paper presents only the second method used in the investigation, namely a questionnaire research.

\section{The Method}

In the paper, we present only one of the three methods used in the investigation, namely "questionnaire". This method is generally used in research to obtain new data. The information obtained from the questionnaires is analyzed and only the analysis leads to results that can defend or refute the initial paper. The questionnaires can be divided according to their mean of distribution. At the moment of writing the paper, there was several ways of possible distribution. Questionnaire is one of the standardized techniques which means it can be divided according to the level of standardization of the questions. Level one is closed questions, answers to which have been previously categorized. Level two is open questions, constructed in the way that the answers could be categorized into certain types of phenomena. Level three is open questions, answers to which cannot be categorized in the research field.

\footnotetext{
1 The dissertation's title is "Paradoxes of the Lusitan Identity in the Context of Cultural Transformations in Europe on the Example of Fado" and was defended by the author of the article on January 31, 2014 at Adam Mickiewicz University in Poznań, Poland.
} 


\section{Data Collecting}

This paragraph presents and analyzes questionnaire results obtained among Portuguese society in spring of 2011. The goal of the questionnaire was to learn about the level of perception of the Portuguese of their own identity with an example of fado. During the investigation, the author of the paper searched for the answers to the following questions: (1) What does fado mean to the Portuguese? Does it reflex the Portuguese or even Lusitan soul?; (2) What is the level of perception of the Portuguese as far as the reflection of their national characteristics in fado is concerned and what characteristics they consider national?; (3) What "keywords" in fado are important for the Portuguese?; (4) Are there any other musical genres that can be possibly compared to fado?; and (5) Is fado for the Portuguese so important that they would intend to preserve it for the future generations?.

The questions used in the questionnaire were composed according to the standards proposed by Lutyński (2000) and on the basis of numerous months of trials and analysis and on the basis of the trial investigation. Each of the questions in questionnaire was supposed to generate data, interpretation of which may result in conclusions defending or refuting the thesis. In the attachment to the questionnaire each respondent was informed of the purpose of the research and of the scientific unit on behalf of which the investigation was being conducted.

In order to reach the widest range of respondents, we used three different ways of distribution of questionnaires. The first one was to deliver printed copies to teachers of two schools in Oporto, Portugal. Completed questionnaires were returned via traditional mail. The second way of distribution was sending the digital version of questionnaires via electronic mail and so they were returned. The third way was an on-line questionnaire $^{2}$ link to which was published on two Portuguese Internet forums ${ }^{3}$ and on an international social network website ${ }^{4}$. The questionnaires were returned via Internet—directly to an electronic account devoted to the questionnaire.

\section{The Questionnaire}

According to the levels of standardization of questions proposed by Lutyński we used all three levels of standardization in the questionnaire: closed questions, open questions with answers able to categorize, and open questions. The questionnaire consisted of 14 questions, five of which were related to personal data. The other nine were substancial questions. There were 91 respondents to the questionnaire, 47 of whom were women and 44 were men.

\section{The Results}

\section{Fado and the Portuguese-What Is Fado for the Portuguese and What Is the Level of Their Knowledge Concerning Fado?}

According to the results of questionnaires, we can deduce that the Portuguese are profoundly aware of the relation between fado and their national and cultural identity. Thanks to original responses we could build the definition of fado which reflexes the Portuguese cognizance of fado. The definition consists of three elements: (1) The first element describes fado as a musical and literature genre: "Piece of music, typical for Portugal,

\footnotetext{
2 An on-line questionnaire was created and Publisher on "Survey Monkey" (www.surveymonkey.com).

3 The abovementioned forums are: "Portal do fado" (www.portaldofado.net) and "Forum Coimbra" (www.forumcoimbra.com).

4 The abovementioned social network website is "Facebook" (www.facebook.com).
} 
Portuguese national song, traditional song, Portuguese song" (personal interview, Spring, 2011); (2) The second element enriches the definition with information related to the essence carried by fado: "The song about Portuguese history, Portuguese song, which (...) describes the past" (personal interview, Spring, 2011); and (3) The third element brings information about the song's character: "Sad song, which sings destiny in a melancholic way, a song (...) with a strong emotional load" (personal interview, Spring, 2011).

Even more interesting seem to be the replies which in metaphorical way answered the question: What is fado? The definition composed on the basis of these answers would sound as follows:

Fado is a song of the Portuguese, a song which represents its soul, its history. Fado is history and culture of that nation. It is life of the Portuguese: joyful and painful. Fado is the cultural heritage. It's the Portuguese pride. (personal interview, October 15, 2011)

The question of nationality, relation between fado and the Portuguese, function of expression the Portuguese soul, their history and life - appeared in almost all the answers which defined fado metaphorically. In the answers, there were real examples through which the Portuguese define fado as a method of expressing grief at history: "Fado is (...) the sadness of the nation, which has to live squeezed in between the powerful Spain and the sinister sea, it is the feeling of inferiority which defines the essence of being Portuguese" (personal interview, Spring, 2011).

In the interview conducted on the purpose of the investigation a fado singer, Rosinda Maria, when asked about what fado was to her, she described this phenomenon as follows:

[Fado] means so much that noone can answer this. Fado is destiny. Fado as a song? Everything that happens is fado. People do not happen/It is only voice, not fado, only voice. You have to feel fado. It is difficult to explain but fado is just destiny. And to me it is the way of expressing myself: the good things and the bad things. It is the state of your soul. I survived two serious breakdowns and I do not know how would I survive without fado? (personal interview, October $15,2011)$

The investigation showed that the Portuguese consider fado as typically Portuguese songs, that arise from Portuguese tradition, though part of the respondents claimed that fado was formed by contacts of the Portuguese with other cultures. The Portuguese, when asked about similarities of fado to other national music genres, considered characteristic for those countries and nations, they indicated similarities of fado to Cape Verde Isands music - "morna music". This music, just like fado, can be defined by the sad atmosphere. Surprisingly often in the lyrics of morna appears a familiar word "sodade" which is derived from Portuguese "saudade". Perhaps then, on the Cape Verde Islands in morna music, the form of expression of Lusitan soul was saved, due to the same reason which tells to sing fado in Portugal.

\section{Fado and Other Cultures}

The results show that the respondents consider fado so strongly tied to their own nation, history, and places in Portugal, that this makes impossible for foreigners to understand completely the message of fado. Nevertheless, the fado singer, Cátia Sofia, when asked about the possibility (or lack) of perception of fado by the foreigners, she replied as follows: "Many tourists say that they do not understand the lyrics but they understand the message that we try to transmit through fado. There are some who start crying not even knowing why" (personal interview, October 15, 2011). 
Previously mentioned fado singer, Rosinda Maria, expressed similar opinion on the way of transmission of fado essence throughout appropriate fado performance:

Not everyone can understand fado. There are some who like light pieces like $<$ A casa portuguesa $>$, because they knew Amália. Others do not understand but they feel. If they do not understand the lyrics they understand something beyond the words. It is the feeling. They feel it. They understand it. That is true. (personal interview, October 15, 2011)

The results of the questionnaire may seem surprising as the respondents compared more frequently fado to morna-Cape Verde Islands music - a small, politically and economically insignificant country, than to Brasilian bossa nova. Whereas it might be due to fears of the Portuguese of being dominated by Brasil in another domain (after being dominated politically, economically and after Portuguese language had been standardized to Brasilian version). Choosing morna music the Portuguese made safer choice as in relation with Cape Verde Islands Portugal intends to play the leading role.

\section{Fado as Heritage}

The investigation revealed that the Portuguese definitively care about saving fado for future generations. Therefore, it can be deduced that among the Portuguese there is cognizance of the need of preserving fado as cultural heritage of their nation. The investigation results were additionally confirmed by the fact that Portugal fought for fado to be recognized as the Intangible Cultural Heritage of Humanity by UNESCO (United Nations Educational, Scientific, and Cultural Organization). On November 27, 2011, it was officially inscribed on the Representative List of the Intangible Cultural Heritage of Humanity in 2011.

With their efforts, the Portuguese proved that fado is a creative contribution to international culture and that they present Portuguese identity, and most importantly, that they are aware of how precious is that treasure to their nation and even humanity:

From now on fado is no longer the song of Portugal, song of Severa, Marceneiro, Amália, Carlos do Carmo, Camané, Ana Moura and Carminho ${ }^{5}$-it is an international treasure. The treasure that tells about Portugal, its culture, language, its poets and the universal truth included in feelings: pain, jealousy, loneliness, love. (Canelas, 2011, p. 3)

During the interview, a fado singer, Rosinda Maria, when asked about the future of fado and possible existence of new generation of fado, she answered providing a vivid illustration to questionnaire results:

There are many [young fado singers], some really good, others not that much theses days. But there are many. In the past, singing fado was a shame. Not now. It is even a trend, well perceived when you sing fado. It was all bad in the past - it is good now. I did not tell anyone [that I sang fado]. There was a restaurant where everyone went and one day a group of people from the university came over; when they saw me, they said: "you never told us you sang fado". And that is true-I never said that. It was a TABOO. That is how it used to be. (personal interview, October 15, 2011)

The statement above was said by a fado singer related for over 20 years with fado. Quite the contrary, a 19-year old fado singer describes her relation with fado, how her personality was formed, how she grew up to become fado singer and quite contrastive attitude of her peers towards her passion - these are a very colorful illustration of young generation of fado singers:

I started to sing when I was 6-7 years old. My grandmother went to fado houses, here in Oporto. She used to go and

5 All the abovementioned are eminent personalities of history of fado. 
she used to sing, and I joined her and... that's what my fascination towards fado comes from. I'm not a professional musician... though everyone thinks so. (personal interview, October 15, 2011)

The abovementioned statement illustrates well how along the last decade the international popularity of fado increased and more importantly, how the awareness of fado among the Portuguese. Perhaps, if we had carried this investigation several years earlier, they would have given completely different results. Nowadays however, there is great interest in fado and increase of positive attitude of the Portuguese towards fado.

Rediscovering fado and excitement about it, may be a desperate attempt to save Lusitan identity. The Portuguese searched for something they could offer in Europe and they discovered, that in fact the best they can do is to suffer and to sink into deep melancholy. Independently if the renaissance of fado is the result of the increase of the conscience of the Portuguese about how important national identity carrier is fado in opposition to the phenomenon of cultural unification in Europe, or an attempt to use current trend towards fado-all actions undertaken due to this boom help to preserve fado. The Portuguese cannot imagine Portugal without fado.

\section{Fado as a Lusitan Identity Screen-Portuguese Portrait in Fado}

The investigation results revealed cognizance of the Portuguese regarding characteristics of their nation. Recognizing "sentimentalism" as the characteristic which best describes the Portuguese in fado, the respondents proved that they are a nation which does not hesitate to express their emotions or remembering their past. "Melancholy" was the second mostly chosen answer by the respondents. This result proves that the Portuguese are the nation for which not only the feelings are extremely important but also pondering and expressing them.

More than half of the respondents claimed that the characteristic that describes Portuguese nature is "passion". One more time the Portuguese openly confirm that one of the most important national characteristics is for them the one related with feelings and their expression. The results connected with the characteristics "romanticism" (this characteristics resulted in the fifth place out of 20 possible) confirm this paper. This means that for the Portuguese, the key question is expressing feelings and the ways of achieving it. The results reveal also that the Portuguese consider themselves as a nation which can be described as tied to tradition (more than half of the respondents made such choice), whereas it is definitely not modernity (only five of the respondents made such choice).

The results show that the respondents consider themselves as the Portuguese (Lusitanians) in contrast to the Europeans or Brazilians. The characteristic that depicts their nation is nationalism (26 respondents chose such answer) and not being a citizen of Europe (none of the respondents made such choice!). It is not the famous "openness of the southerners" that the Portuguese consider their national characteristic in fado as only six of the respondents made such choice. Despite the fact that Portugal is considered a country inhabited by the Catholics the Portuguese do not consider themselves as religious. Only nine of the respondents stated that it is a characteristic that depicts their nation.

The results of the investigation carried out reveal that the Portuguese do not consider themselves as a hard-working nation - only two respondents chose this option of the answer.

The investigation proves that the Portuguese are rather critical and objective when describing their own nation. The picture of the Portuguese achieved thanks to the investigation presents on one hand sensitive and emotional nation, on the other hand a nation closed and metaphorically isolated from today's world. The 
research shows that the Portuguese unanimous about the fact that fado is their identity carrier or, in other words the carrier of the Portuguese soul.

What is the "Portuguese soul" then? de Pascoaes (1998), Portuguese poet and philosopher from the 20th century, literary movement "Portuguese renaissance" mentor, described the soul of Portuguese nation through the "saudosismo". The name of the current comes from the Portuguese word "saudade" considered by many Portuguese as untranslatable into any other language (such statements occur also in respondents' answers). The word "saudade" does not mean a temporary longing. It is a way of life and way of being of the Portugues - unstoppable waiting for someone or something. It is longing for a lover who went to unknown sea, it is homesick for the family who stayed in a port town. But it is also the longing for the golden age of Portugal, for its lost power and influence. It is hoping for those times to come back. "It is the atmosphere of awaiting king Sebastian to come back" who would appear in the misty dawn on a white horse. This picture is the essence of the myth of king Sebastian, interpretation of which led to create "sebastianism"-a belief that the golden times of Portugal would come back with king's Sebastian comeback. de Pascoaes (1998) combined saudosismo with sebastianism giving it new, enlightened form. de Pascoaes (1998) describing "the soul of the Portuguese nation" underlines the importance the paradox that creates that soul:

The soul of our nation is characterized by the Aryan and Semitic element with their different vision of the role of an individual. These joined and not opposed elements lead to the ferment that stimulate our country and add significance to it. (p. 26)

Portuguese historian Martins in his work "História de Portugal" (2004) described sebastianism as a very specific form of national Messianismzmu characteristic for the Portuguese nation. Sebastianism is a "posthumous testimony of nationality" and it is in the sebastianism that "the spirit of the race" expresses its Celtic roots and national awareness (Martins, 2004).

\section{Axio-linguistic Auto-portrait of a Portuguese in Fado-Conclusions}

The starting point of the investigation was the paper saying that fado can contain and can actually be the source of the Portuguese national identity expression. During the investigation, the paper gradually evolved broadening the spectrum of our interests with cultures related in various ways to the Portuguese. In today's world, in which pop culture means mass culture, is formless, nameless - culture of everyone and of none, fado seems to be an irrational relic of the past, abundant with identity of a cultural circle in which it came to existance. Entering the European Union, the Portuguese start searching for their identity in their own destructiveness. The Portuguese are not interested in technological race. They hide in their uniqueness based on barely constructive folklore, a culture and civilization heritage park. It is a natural phenomenon that in Europe, which gradually becomes post-national and post-religious, with a free labor market, small nations defend themselves against loosing their own identity.

The research helped in obtaining original and interesting portrait of a Portuguese, which turns out not to be necessarily favorable for them. A Portuguese stands turned backward to Europe, to progress and to future. A Portuguese faces the sea. Stands in the mist of melancholy waiting for king Sebastian to come back. Such attitude reveals inability of a Portuguese to take up new challenge and to face the future. A Portuguese stands on the cross-roads: He wishes to see what interesting is happening in the world, but on the other hand, he is paralyzed 
with unstable position in the world's history. A Portuguese does not want to start walking forward-he stands, recalling the painful experiences of disgraceful but glorious past and uncertain and frightening future. Lamentation reflected not only in music but also in lyrics of fado is a kind of self-flagellation and demonstration in front of the world how terrible and unjust Portuguese fate is. In Portugal, the entire emotional load, condensed and ready to explode with frustration and melancholy — is crystallized in fado. The investigation conducted by us completed the current state of the knowledge on fado with a new view — as from a different perspective.

\section{References}

Bartmiński, J. (2000). Językowy obraz świata jako podstawa tożsamości narodowej (Linguistic view of the world as the basis of the national identity). In T. Kostryrko, \& T. Zgółka (Eds.), Kultura a kręgi tożsamości (Culture and the identity circles) (pp. 152-167). Poznań: Wielkopolskie Towarzystwo Kulturalne.

Bartmiński, J. (2006). Językowe podstawy obrazu świata (The basis of the linguistic view of the world). Lublin: Wydawnictwo UMCS.

Barzini, L. (2001). Europejczycy (The Europeans). Warszawa: Warszawskie Wydawnictwo Literackie MUZA S.A..

Bell, A. F. G. (1915). Portugal of the Portuguese. New York: C. Scribner's Sons.

Bernstein, B. (1990). Odtwarzanie kultury (Structuring culture). Warszawa: Państwowy Instytut Wydawniczy.

Canelas, L. (2011). O fado já é o património mundial (Fado is already global heritage). Lisboa: Público.

de Pascoaes, T. (1998). Arte de ser Português (The art of being a Portuguese). Porto: Assírio \& Alvim.

Foucault, M. (2002). Porzadek dyskursu (The order of things). Gdańsk: Słowo/Obraz Teoria.

Freyre, G. (1985). Panowie i niewolnicy (The masters and the slaves). Warszawa: Państwowy Instytut Wydawniczy.

Gellner, E. (1991). Narody i nacjonalizm (Nations and nationalism). Warszawa: Państwowy Instytut Wydawniczy.

Giddens, A. (2004). Socjologia (Sociology). Warszawa: Wydawnictwo Naukowe PWN.

Giddens, A. (2007). Nowoczesność i tożsamość (Modernity and self-identity). Warszawa: Wydawnictwo Naukowe PWN.

Gouveia, D. (2010). Ao Fado Tudo se Canta? (About fado you only can sing?). Lisboa: DG Edições.

Lutyński, J. (2000). Metody badań społecznych. Wybrane zagadnienia (The choice of sociological research methods). Łódź: Łódzkie Towarzystwo Naukowe.

Martins, O. (2004). História de Portugal (History of Portugal). Guimarães: Guimarães Editores.

Nery, V. R. (2004). Para uma história do fado (Towards history of fado). Lisboa: Público/Corda Seca.

Siewierski, H. (2006). Wstęp do Przestania Fernando Pessoy (Introduction to the Pessoa's “Message”). Warszawa: Wydawnictwo Studiów Iberyjskich i Iberoamerykańskich UW.

Tomalak, K. (2009). Czasowniki "być" w języku portugalskim—Problemy semantyczne a dydaktyka (Portuguese verbs "to be"-Semantic problems and didactics). Investigationes Linguisticae, XVIII, 100-111.

Tomalak, K. (2011). Fado-Portugalska dusza? (Fado-A Portuguese soul?). In A. Piotrowicz, B. Jezierska, \& M. Sulińska (Eds.), Tom pokonferencyjny: Language-A meeting place, Poznańskie studia Polonistyczne (Conference proceeding volume: Language-A meeting place, Poznań Polish language studies). Poznań: Wydawnictwo Poznańskie Studia Polonistyczne.

Tomalak, K. (2013). Portugalskie pieśni fado jako nośnik tożsamości kulturowej (Fado as a cultural identity carrier). Tom pokonferencyjny: Wspólnoty komunikacyjne (Conference proceeding volume: Communication communities) (pp. 97-108). Poznań: Wydawnictwo Poznańskiego Towarzystwa Przyjaciół Nauk. 